\title{
PENGEMBANGAN APLIKASI WEB-COMMERCE PT. WGS SEBAGAI MEDIA PROMOSI
}

\author{
Lina $^{1}$, Bagus Mulyawan ${ }^{1}$ dan Daniel Ajienegoro ${ }^{2}$ \\ ${ }^{1}$ Fakultas Teknologi Informasi, Universitas Tarumanagara. Jakarta \\ Email: lina@untar.ac.id \\ Email:bagus@untar.ac.id \\ ${ }^{2}$ Konsultan Independen Mitra, Jakarta. \\ EmailL daniel.a71e@gmail.com
}

\begin{abstract}
PT. WGS is a micro business engaged in the provision of premium and imported food and beverage sector. The problems faced by PT. WGS as a newly established business is that most of its operational activities, namely the marketing process, sales process, inventory recording, and others are still conducted manually. To market its products, PT. WGS has carried out marketing activities by uploading product catalogues on various online applications in well-known e-commerce marketplaces, such as Tokopedia, Shopee, Instagram, and similar applications. As a form of higher education involvement in supporting the development and survival of micro businesses, the authors who are also the community service activity team (PKM) design a website that can help as a promotional media for PT. WGS as a PKM partner. The development process starts from system requirements analysis, interface design, website development, testing of all functions and modules, and system implementation on the company's website domain. The system development method will follow the Software Development Life Cycle (SDLC) stages. The output produced in this PKM activity is the web-commerce of PT. WGS which is implemented as one of the company's promotional media that is expected to increase the number of product sales from PT. WGS.
\end{abstract}

Keywords: website, e-commerce, promotional media.

\begin{abstract}
ABSTRAK
PT. WGS merupakan usaha mikro yang bergerak di bidang penyediaan makanan dan minuman premium yang diimpor dari luar negeri. Permasalahan yang dihadapi oleh PT. WGS sebagai usaha yang baru berdiri adalah sebagian besar dari kegiatan operasionalnya, yaitu proses pemasaran, proses penjualan, pencatatan inventori, dan lainnya masih dilakukan secara manual. Untuk memasarkan produk yang dimilikinya, PT. WGS telah melakukan kegiatan pemasaran dengan memuat katalog produk pada aplikasi online yang terdapat pada marketplace ecommerce ternama, seperti Tokopedia, Shopee, Instagram, dan aplikasi sejenisnya. Sebagai bentuk keterlibatan perguruan tinggi dalam mendukung berkembangnya dan bertahannya usaha mikro, penulis yang juga merupakan tim pelaksana kegiatan pengabdian kepada masyarakat (PKM) ini melakukan perancangan web-commerce yang dapat membantu sebagai media promosi untuk PT. WGS sebagai mitra PKM. Proses pengembangan dimulai dari analisis kebutuhan sistem yang diinginkan mitra, membuat desain tampilan antarmuka, melakukan pengembangan website, melakukan pengujian terhadap keseluruhan fungsi dan modul yang terdapat pada website, serta melakukan implementasi sistem yang berjalan pada domain website yang dimiliki perusahaan. Metode pengembangan sistem dilaksanakan dengan mengikuti tahapan Software Development Life Cycle (SDLC). Luaran yang dihasilkan pada kegiatan PKM ini adalah website commerce PT. WGS yang diimplementasikan sebagai salah satu media promosi perusahaan yang diharapkan dapat meningkatkan jumlah penjualan produk dari PT WGS.
\end{abstract}

Kata Kunci: website, e-commerce, media promosi.

\section{PENDAHULUAN}

Seiring dengan perkembangan teknologi informasi, terjadi pula pergeseran orientasi dalam dunia usaha dan organisasi yang semakin banyak melibatkan penggunaan teknologi komputer serta telekomunikasi secara signifikan. Penggunaan teknologi ini meliputi keseluruhan aspek dalam operasional perusahaan, baik pemasaran, penjualan, inventori, logistik, maupun analisis bagi eksekutif. Target yang ingin dicapai oleh perusahaan baik profit maupun non-profit tentunya adalah untuk meningkatkan kinerja perusahaan.

Bidang bisnis dan perdagangan yang berkembang saat ini sangat terpengaruh dengan perkembangan teknologi informasi khususnya dalam penggunaan internet (Jauhari, 2010). Online shop merupakan sarana atau toko untuk menawarkan barang dan jasa lewat internet sehingga 
pengunjungnya dapat melihat barang-barang di toko secara online (Sari, 2015). Selanjutnya, transaksi jual beli banyak dilakukan melalui media internet atau e-commerce, seperti pada situs marketplace seperti Tokopedia, Shopee, Bukalapak, dan sebagainya. Bagi calon pembeli, setelah melakukan pemilihan terhadap produk yang diinginkan dan melakukan transaksi pembayaran secara online, pembeli dapat menunggu pengiriman ke alamat yang dituju. Pembeli mendapatkan kemudahan yaitu tidak perlu keluar rumah untuk berbelanja. Sedangkan bagi penjual, keberadaan toko online memudahkan pemasaran sehingga keberadaan toko serta katalog produk yang dijualnya dapat diakses oleh seluruh penjuru dunia yang memiliki akses internet.

Mitra pada kegiatan pengabdian kepada masyarakat ini adalah PT. WGS yang merupakan usaha mikro yang menjual berbagai makanan, mulai dari makanan instan hingga bumbu masak. Selain itu, PT. WGS juga menyediakan berbagai macam produk minuman, seperti minuman soda, hingga minuman instan (kopi dan teh). Lokasi dari PT. WGS berada pada Ruko Mendrisio, Tangerang, Banten. Sebagaimana toko online, penjualan produk dilakukan melalui aplikasi online ternama seperti Tokopedia, Shopee, dan Blibli.com. Sedangkan proses pencatatan penjualan, stok barang, pengecekan tanggal kadaluarsa produk masih dilakukan secara manual. Hal ini tentunya sangat tidak efektif dan efisien dalam pemrosesan pesanan dalam jumlah besar. Selain itu pencatatan stok dan pemeriksaan kadaluarsa secara manual juga sangat rentan terhadap human error.

Mengikuti tren terkini bahwa penjualan produk juga dapat dilakukan melalui media sosial yang tidak berbayar atau tidak terkena biaya administrasi. Banyak toko online yang kemudian melakukan pemasaran melalui media sosial, seperti Instagram, Facebook, dan media lainnya. PT. WGS sebagai pelaku usaha mikro juga berusaha mengikuti tren ini. Gambar 1 menampilkan tampilan informasi toko online PT. WGS melalui media Instagram. Pemasaran produk melalui situs marketplace ternama dan media sosial tentu saja sangat membantu PT. WGS untuk meningkatkan pemasaran/penjualan dengan biaya yang rendah.

\section{Gambar 1}

Tampilan Informasi Toko Online PT. WGS Melalui Instagram

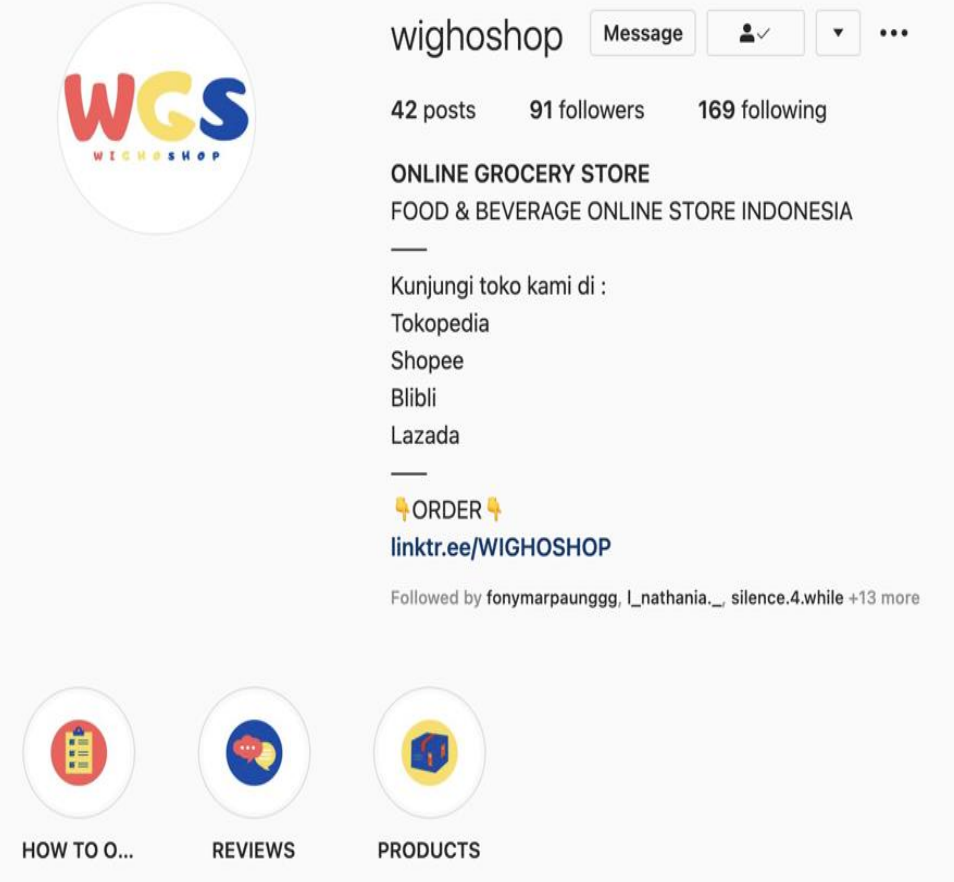




\section{Gambar 2}

Tampilan Katalog Produk PT. WGS Pada Situs Marketplace Tokopedia

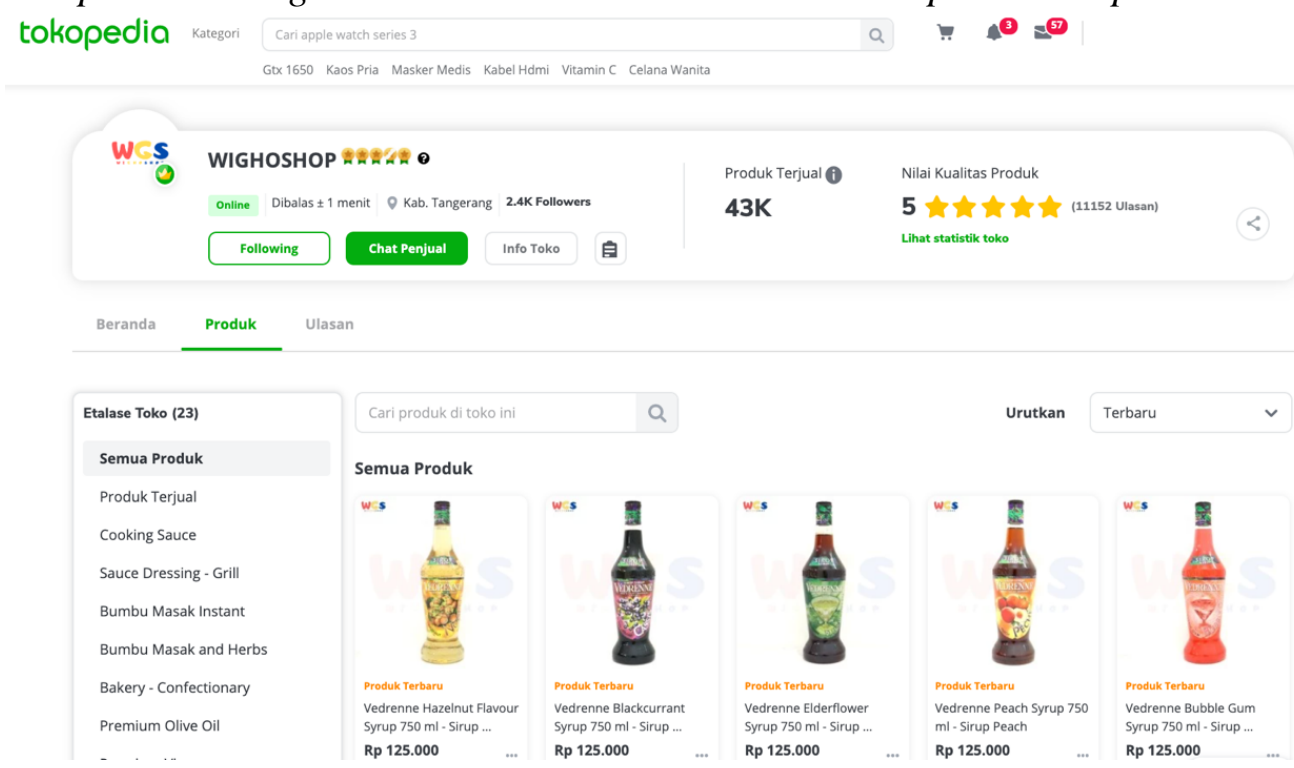

\section{Gambar 3}

Tampilan Katalog Produk PT. WGS pada Situs Marketplace Shopee

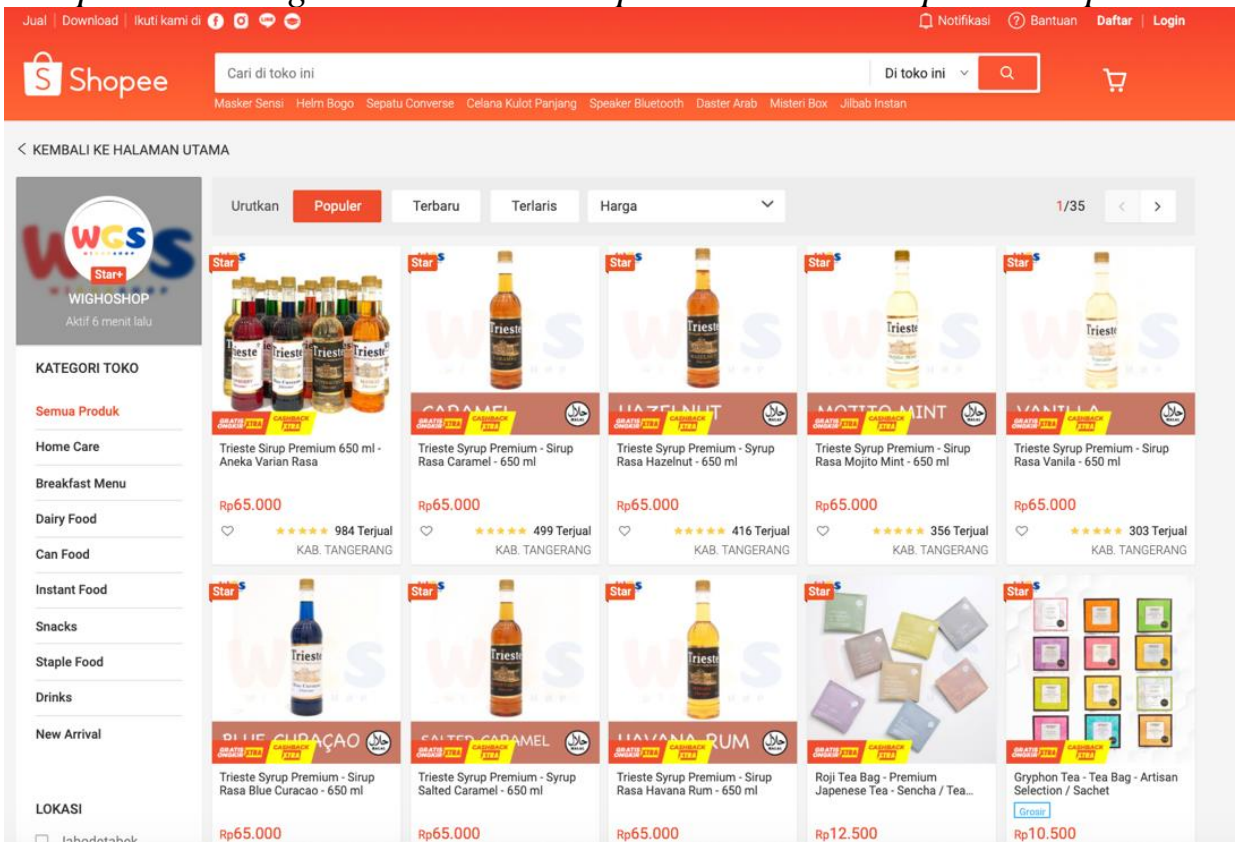

Secara umum, proses pemesanan produk pada PT. WGS adalah sebagai berikut 1) Calon pembeli memilih produk yang tersedia dan melakukan transaksi pembelian di e-commerce ternama, 2) Pemilik merespon dan memproses pesanan, 3) Pemilik toko melakukan permintaan pickup sesuai dengan ekspedisi yang dipesan oleh pembeli, 4) Barang dikirim oleh kurir ekspedisi (pihak ketiga), 5) Pesanan tiba di alamat pembeli dan pembeli mengkonfirmasi selesainya pesanan, 6) Dana pembelian diterima oleh pemilik toko. Proses ini dilakukan untuk setiap transaksi pembelian yang terjadi. Selanjutnya, pemilik dari PT. WGS akan melakukan rekapitulasi penjualan serta pembaruan stok secara manual. Proses ini telah dijalankan selama beberapa tahun sejak PT. WGS didirikan. Gambar 2 dan Gambar 3 menunjukkan tampilan katalog toko online PT. WGS pada situs marketplace Tokopedia dan Shopee secara berurutan. 
Namun demikian, PT. WGS masih harus mengalokasikan dana untuk penyewaan tempat penyimpanan produk serta usaha keras untuk pencatatan transaksi dan stok barang secara manual. Gambar 4 menampilkan tempat penyimpanan produk PT. WGS. Melalui deskripsi di atas, situasi yang terjadi pada PT. WGS saat ini dapat dikatakan masih bergantung pada promosi melalui media sosial dan proses penjualan melalui situs marketplace. Selain itu, proses pencatatan stok barang dan rekapitulasi penjualan juga masih dilakukan secara manual oleh pemilik dan staf toko.

Gambar 4

Tampilan Tempat Penyimpanan PT. WGS

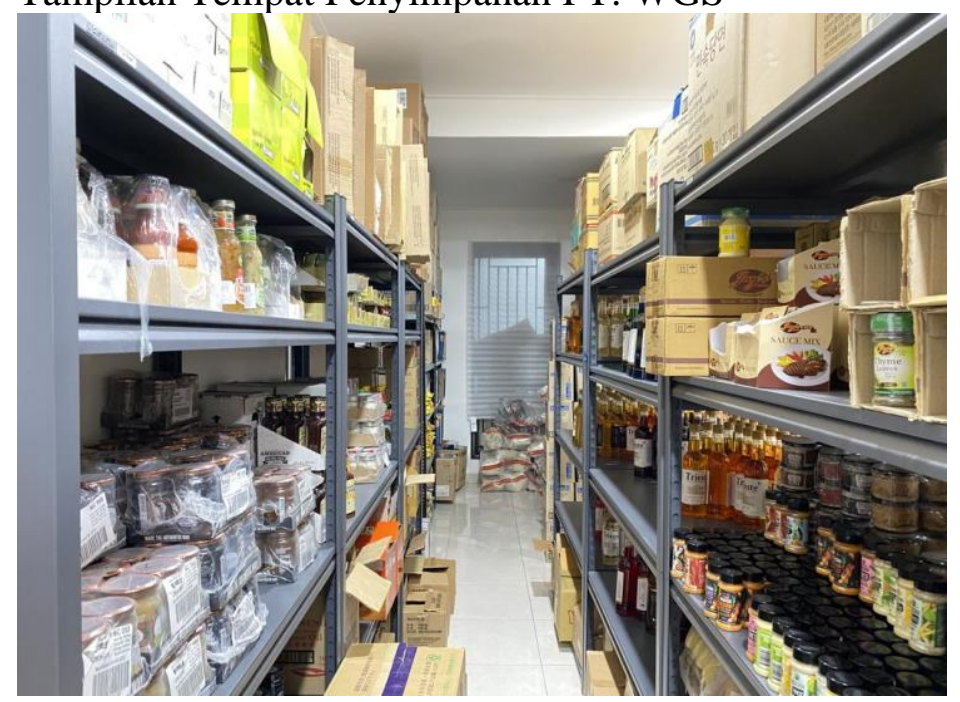

Masalah utama yang dihadapi oleh mitra adalah belum adanya media promosi yang dapat menampilkan katalog produk dan memproses penjualan secara online yang dikelola sepenuhnya oleh PT. WGS. Sejauh ini, pemilik mendaftar pada beberapa situs marketplace terkenal seperti Tokopedia, Shopee, dan pada media sosial seperti Instagram. Akan tetapi, pada situs tersebut, PT. WGS harus bersaing dengan keberadaan toko lainnya serta masih harus melakukan pencatatan rekapitulasi transaksi penjualan secara manual.

Untuk membantu masalah dari usaha mikro di atas, penulis yang juga merupakan tim pelaksana pengabdian kepada masyarakat mengusulkan perancangan dan pembuatan website untuk PT. WGS yang dapat dikelola sepenuhnya oleh pemilik. Tim pelaksana pengabdian kepada masyarakat akan melakukan analisis kebutuhan dengan wawancara kepada pemilik, membuat rancangan purwarupa, pengujian, serta implementasi pada PT. WGS. Luaran dari kegiatan ini adalah berupa purwarupa website yang diharapkan membantu PT. WGS meningkatkan promosi usahanya.

PT. WGS masih mengandalkan toko online yang berada pada situs marketplace ternama seperti Tokopedia, Shopee, serta media sosial seperti Instagram. Demikian pula untuk rekapitulasi transaksi penjualan dan stok barang, PT. WGS melakukannya secara manual oleh pemilik serta staf toko. Hal ini sangat tidak efisien dikarenakan membutuhkan waktu pengerjaan yang cukup lama serta berpeluang besar mengalami kesalahan akibat human error. Untuk mengatasi masalah ini, tim pelaksana pengabdian kepada masyarakat mengusulkan pembuatan website untuk PT. WGS yang diharapkan dapat menjadi media promosi baru bagi perusahaan.

Salah satu penerapan ICT dan internet dalam bidang bisnis dan perdagangan adalah electronic commerce (e-commerce) (Dewi, 2014). Manfaat dan keuntungan menggunakan e-commerce 
adalah sebagai media promosi dalam rangka meningkatkan volume penjualan, baik untuk penjualan online maupun konvensional (Supardi \& Dores, 2009). Kegiatan promosi merupakan sebuah unsur dalam pemasaran yang didayagunakan untuk memberitahukan, membujuk, dan mengingatkan tentang produk perusahaan (Denny, 2013). Promosi dapat menggunakan berbagai media dan saluran informasi yang ada untuk menampilkan informasi terhadap produk barang atau jasa yang dipasarkan. Selain itu, promosi juga melibatkan kalimat persuasif untuk menarik calon pembeli. Dengan menggunakan teknologi, kegiatan promosi dapat dilakukan dengan lebih menarik dengan melibatkan teks dinamis, grafik, gambar, suara, animasi, atau bahkan video. Selain itu, kegiatan promosi berbasis teknologi memiliki keuntungan dari segi kemudahan pembaharuan informasi serta biaya yang lebih murah dibandingkan dengan metode konvensional.

Kegiatan pengabdian kepada masyarakat di usaha mikro PT. WGS ini memiliki fokus untuk merancang website sebagai media promosi utama. Website yang dibuat ini nantinya dapat digunakan oleh mitra untuk menampilkan informasi perusahaan, katalog produk yang dijual, serta pencatatan transaksi penjualan. Melalui website ini pembeli dapat memilih produk yang ingin dibeli, memasukkannya ke keranjang belanja, dan menerima informasi cara pembayaran terhadap pembelian. Sementara, bagi pemilik toko, terdapat notifikasi bagi penjual jika ada transaksi pembelian dari pembeli yang meliputi tanggal pemesanan, produk yang dipesan, serta informasi pembayaran. Selanjutnya, mitra dapat melakukan pemrosesan terhadap pesanan jika pembelian telah terkonfirmasi dan memberikan informasi tracking pesanan sesuai kurir yang dipilih. Informasi pengiriman pesanan hingga selesainya pesanan dapat dipantau oleh kedua belah pihak.

Selain transaksi penjualan, website yang dirancang ini juga menampilkan informasi yang dapat ditentukan dan diperbaharui secara mandiri oleh penjual, seperti informasi profil perusahaan, sejarah berdirinya perusahaan, informasi produk baru, harga promo terhadap produk tertentu, voucher terhadap pembelian dengan jumlah tertentu, serta ulasan lainnya. Keberadaan website ini juga dapat memperlancar operasional perusahaan terkait pencatatan rekapitulasi penjualan, pencatatan stok barang, notifikasi terhadap stok yang menipis, dan lain sebagainya. Dengan media ini, diharapkan fokus dari pemilik dapat diarahkan pada pengelolaan inventori dari perusahaan serta koordinasi dengan supplier.

Media baru yang dirancang yaitu berupa website PT. WGS tidak ditujukan untuk menggantikan media lainnya, melainkan berfungsi sebagai media promosi tambahan bagi perusahaan mitra. Hal ini disebabkan karena mitra masih membutuhkan media lainnya untuk mempertahankan penjualan, serta implementasi sistem baru memerlukan pelatihan khusus selama beberapa waktu tertentu bagi pemilik maupun staf di PT. WGS yang tidak memiliki latar belakang pendidikan komputer. Namun demikian, mitra akan melakukan evaluasi terhadap efektivitas penggunaan keseluruhan media secara periodik dan mengharapkan keberadaan website dengan sistem yang lengkap dapat menjadi media utama bagi kegiatan operasional PT. WGS di masa depan. Sesuai dengan solusi yang diusulkan oleh tim pelaksana kegiatan pengabdian kepada masyarakat untuk permasalahan mitra PT. WGS berupa purwarupa website PT.WGS sebagai media promosi.

\section{METODE PELAKSANAAN PKM}

Dalam bidang teknologi informasi, terdapat tahapan pengembangan terhadap suatu perangkat lunak termasuk pengembangan website yang dinamakan dengan Software Development Life Cycle (SDLC). Tahapan proses yang terdapat dalam rekayasa web mencakup perencanaan, analisis, perancangan, pengujian, serta implementasi sistem. 
Pada pengembangan website untuk PT. WGS ini akan digunakan metodologi waterfall model untuk mengakomodasi permintaan user serta menjamin kesesuaian rancangan yang dihasilkan. Personil yang terlibat dari PT. WGS adalah pemilik usaha beserta beberapa orang staf. Pemilik usaha berperan dalam memberikan informasi kebutuhan sistem dan rancangan website yang diinginkan. Selain itu, pemilik usaha juga menyediakan katalog produk (termasuk foto, deskripsi, dan harga), contoh toko online yang dimiliki mitra yang saat ini masih aktif di dalam situs marketplace, serta bersedia menjadi administrator website yang akan dibuat bersama dengan beberapa staf lainnya.

Pada tahap pertama dalam pengembangan sistem, dilakukan beberapa analisis terhadap hal berikut, yaitu (Susanto \& Asmira, 2017):

1. Estimasi: dilakukan estimasi waktu, biaya dan sumber daya yang diperlukan dalam pengembangan sistem

2. Analisis resiko: dilakukan diskusi antara user dengan tim pengembang mengenai resiko apa yang mungkin terjadi

3. Penjadwalan: dilakukan pembuatan jadwal rinci oleh project manager dan menjelaskan bagaimana urutan modul dikembangkan

4. Monitoring: dilakukan untuk mengawasi kegiatan proyek, jadwal kerja, dan penggunaan sumber daya

Tahapan selanjutnya adalah membuat rancangan (design) terhadap tampilan antar muka website dan tabel basis data yang dibutuhkan. Rancangan akan dibuat oleh tim pelaksana kegiatan pengabdian kepada masyarakat dan dikomunikasikan dengan pihak PT. WGS sebagai end user.

Pada tahap pengembangan, akan digunakan bahasa pemrograman PHP dengan memadukan konsep model, view, controller, dan desain tampilan menggunakan bootstrap. Pengembangan sepenuhnya akan dikelola oleh tim pelaksana kegiatan pengabdian kepada masyarakat. Jadwal pengembangan juga diupayakan sesingkat mungkin untuk kemudian dilakukan pengujian dengan data mitra dan kesesuaian terhadap keinginan user.

Tahap pengujian diawali dengan melakukan pengujian terhadap setiap modul dan fungsi yang ada pada website. Selanjutnya dilakukan pengujian oleh mitra dalam bentuk user acceptance test. Jika terdapat ketidaksesuaian, maka tim segera melakukan perbaikan dan pengujian ulang. Tahapan terakhir dalam pengembangan sistem ini adalah tahap implementasi. Tahap ini dilakukan pada lokasi mitra dengan peralatan yang dimiliki oleh mitra. Proses implementasi juga dilakukan melalui hosting pada domain yang telah disewa. Pada tahap ini juga dibuka kesempatan bagi pemilik dan staf toko untuk belajar menggunakan sistem yang telah dikembangkan.

\section{HASIL DAN PEMBAHASAN}

Dalam mengembangkan website sebagai media promosi bagi PT. WGS, dilakukan diskusi antara user dengan tim pelaksana PKM. Diskusi mencakup user interface serta fungsi yang diinginkan oleh user. Bentuk tampilan menu beranda dari website yang dikembangkan tertera pada Gambar 5. Website yang dirancang tetap mempertahankan sebanyak mungkin media dan koneksi dengan marketplace yang telah digunakan oleh PT. WGS untuk menerima order hingga saat ini. Tampilan dari menu koneksi dengan marketplace tertera pada Gambar 6. Sedangkan untuk tampilan dari sisi backend terlihat pada Gambar 7 yang merupakan tampilan untuk menu login untuk beberapa tingkatan user, serta Gambar 8 yang merupakan tampilan untuk dashboard administrator yang mencakup daftar pengguna, daftar produk, daftar pesanan, pesan masuk, dsb. 


\section{Gambar 5}

Tampilan Menu Beranda Pada Website PT. WGS

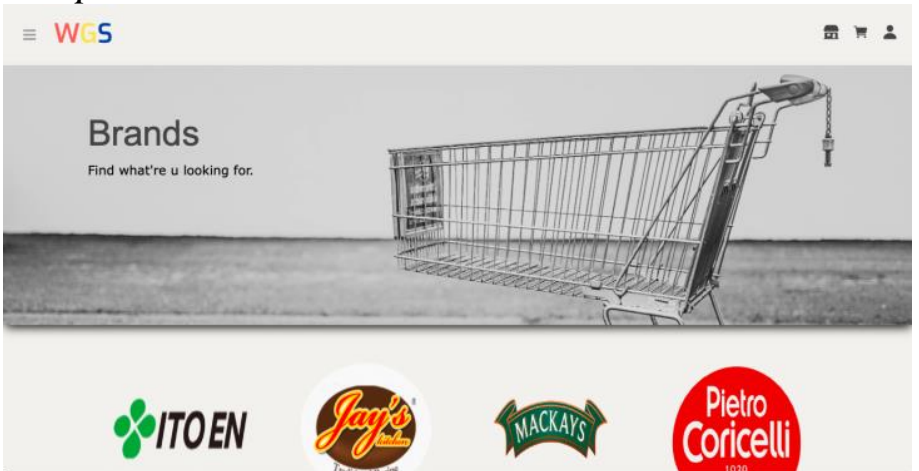

\section{Gambar 6}

Tampilan Menu Koneksi dengan Marketplace pada Website PT. WGS

$\equiv \mathrm{W} S \mathrm{~S}$

$$
\text { 표 }
$$

Our Best Choice
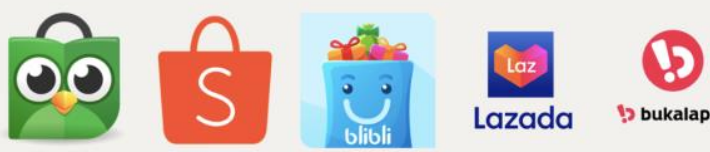

Lazada

to bukalapak
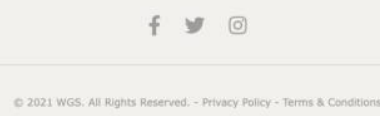

\section{Gambar 7}

Tampilan Menu Login untuk Beberapa Tingkatan User pada Website PT. WGS

$$
\text { WGS }
$$
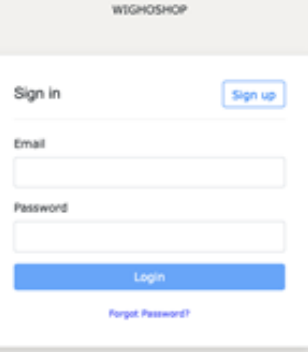

\section{Gambar 8}

Tampilan Dashboard Administrator pada Website PT. WGS

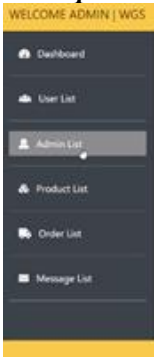

2 DASHBoARD
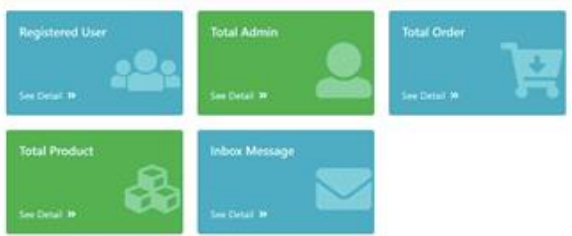
Pengujian blackbox testing telah dilakukan untuk memastikan bahwa setiap menu telah melakukan fungsi yang diinginkan dan mengeluarkan hasil yang sesuai. Selain itu, juga telah dilakukan user acceptance test terhadap website yang dihasilkan dan mendapatkan persetujuan mitra yaitu PT. WGS. Akhirnya tahapan implementasi dilaksanakan dengan diluncurkannya web-commerce ini pada domain perusahaan.

\section{KESIMPULAN DAN SARAN}

Kegiatan pengabdian kepada masyarakat yang dibahas pada makalah ini adalah pengembangan web-commerce sebagai media promosi guna meningkatkan penjualan PT. WGS. Saat ini webcommerce yang dirancang telah diimplementasikan dan beroperasi dengan baik dan sesuai target.

\section{Ucapan Terima Kasih (Acknowledgement)}

Penulis mengucapkan terima kasih kepada Lembaga Penelitian dan Pengabdian kepada Masyarakat Universitas Tarumanagara atas dukungan pendanaan untuk kegiatan Pengabdian kepada Masyarakat (PKM) ini melalui Hibah PKM Periode I Tahun Anggaran 2021 Nomor: 188Int-KLPPM/UNTAR/II/2021.

\section{REFERENSI}

Denny, D. (2013). Promosi dan kualitas layanan pengaruhnya terhadap keputusan konsumen menggunakan jasa pembiayaan pada PT. Bess Finance Manado. Jurnal EMBA, 1(4), 5159.

Dewi, S.K. (2014). Perancangan website sebagai media promosi dan penjualan pada home industry abon. Jurnal Teknik Industri, 15(2), 170-181.

Jauhari, J. (2010). Upaya pengembangan usaha kecil dan menengah (UKM) dengan memanfaatkan e-commerce. Jurnal Sistem Informasi, 2(1), 159-168.

Sari, C. A. (2015). Perilaku berbelanja online di kalangan mahasiswi antropologi di Universitas Airlangga. Jurnal AntroUnairdotNet, 4(2), 205-216.

Supardi, J. \& Dores, V. (2009). Rancang bangun collaborative system pemasaran hotel secara online dengan pendekatan mediator based. Jurnal Sistem Informasi, 1(2), 55-61.

Susanto, A. \& Asmira. (2017). Perancangan website sebagai media promosi dan informasi menggunakan metode web engineering. Jurnal SIMKOM, 2(3), 9-17 